\title{
Geophysics Applied in Civil Engineering: Cases of the Cement Factory of Jebel Ressas (North-East of Tunisia) and the Secondary School of Sidi Aich (South-West of Tunisia)
}

\author{
Asma Hamed Ferjani \\ Unité de Recherches de Géophysique Appliquée aux Matériaux et aux Minerais, Faculté \\ des Sciences de Tunis, Tunis \\ E-mail: ferjaniasma2013@gmail.com
}

\begin{abstract}
Rihab Guellala
Centre de Recherches et de Technologies des Eaux de Borj Cedria, Tunis

Unité de Recherches de Géophysique Appliquée aux Matériaux et aux Minerais. Faculté des Sciences de Tunis, Tunis
\end{abstract}

\section{Mohamed Hédi Inoubli}

Unité de Recherches de Géophysique Appliquée aux Matériaux et aux Minerais, Faculté des Sciences de Tunis, Tunis

\section{Farhat Ben M'Barek}

Office National des Mines, Tunis

Received: May 26, 2014 Accepted: July 9, $2014 \quad$ Published: October 14, 2014

doi:10.5296/jee.v5i2.5692 URL: http://dx.doi.org/10.5296/jee.v5i2.5692

\section{Abstract}

The present study exposes two cases of geophysics use in civil engineering. 


\section{Macrothink}

Case of Jebel Ressas (North-East of Tunisia) -To recognize and characterize the basement of a future cement factory at Jebel Ressas (North -East of Tunisia), 25 vertical electrical soundings are performed using the Schlumberger configuration. The qualitative and quantitative interpretations of the obtained data show that the prospected area is affected by normal faults generating collapses and a remarkable thickening of the clayey layers towards the north and the west. Since many earthquakes marked the Jebel Ressas sector, these faults may be active.

Case of Sidi Aich (South -West of Tunisia) -In order to determinate the factors which damaged the Sidi Aich school (Gafsa gouvernerate, Tunisia) a geophysical study is undertaken . Six vertical electrical soundings are realized. These VES interpretation show that the prospected lithological formations are characterized by facies, thickness and depth variations and affected by two NE-SW faults. The maps established from the VLF data gave more precisions .They identify four faults directed NE-SW to NNE-SSW. The microgravimetric measures dont furnishe any indication about the underground geometry of the Sidi Aich school since the litholgical formations are characterized by similar densities.

Keywords: Geophysics methods, Civil engineering, Jebel Ressas cement factory, Sidi Aich school, Tunisia 


\section{Introduction}

Geophysics provides wide applications in civil engineering studies. It can contribute to different decisions about the construction: site, foundations, maintenance and reparation. In fact, it can interfere in the underground cavities detection (Frappa and Muraour 1980; Beres et al. 2001; El Khammari et al. 2007), the landslides studies (Schmutz et al. 1999; Grandjean et al. 2006), the fractures determination (khalldaoui et al. 2009)....

In this study, we presented two concrete examples of geophysics use in civil engineering studies. The first concerns Jebel Ressas sector (Fig.1a). The second interests Sidi Aich area (Fig.2a).

The Jurassic limestones of Jebel Ressas (North-East of Tunisia) constitute an excellent raw material for cement production. Thus, the implantation of a cement factory in the close proximity of Jebel Ressas appears as an interesting project for the economic and social development of the region.

To recognize and characterize the subsoil of the Quaternary plain located at the foot of Jebel Ressas in view to guarantee the optimal site and adequate foundations for a future cement factory, the electrical resistivity method (Keller and Frischknecht 1982) is adopted. 25 vertical electrical soundings (Fig.1b) with a maximum electrode spacing of $300 \mathrm{~m}$ are realized and interpreted.

The second study case is realized at the request of the Ministry of Education of Tunisia. It concerns the Sidi Aich secondary school (Governorate of Gafsa, South-West of Tunisia) constructed at the foot of Sidi Aich Jebel (Fig.2a). Examining the school buildings, major cracks which affect the walls (Fig .2b) and the piles (Fig.2c) are observed. These cracks are continually opened up. Thus, their infilling is an inappropriate solution to restore the school. To precise the factors generating the cracks which damage the Sidi Aich school in order to determine the suitable corrections and the necessary precautions, three geophysical methods are used (Fig.3):

- 6 Vertical electrical soundings were realized and interpreted. The maximum electrode spacing is $300 \mathrm{~m}$ and the Schlumberger configuration was adopted.

- $\quad 11 \mathrm{VLF}$ profiles were conducted for the frequency $18300 \mathrm{HZ}$

- 12 microgravimetric profiles with a grid spacing of $5 \mathrm{~m}$ were executed.

\section{Used Geophysical Methods}

\subsection{Vertical Electrical Sounding}

The electrical resistivity method (Keller and Frischknecht, 1982) involves the measurement of the resistivity of rocks. Vertical Electrical sounding (VES) method, adopted in this study, is used to determine vertical variations of resistivity. An electrical field is imposed on the inland area by a pair of current electrodes ( $\mathrm{A}$ and $\mathrm{B}$ ). The potential difference is measured between a pair of potential electrodes ( $\mathrm{M}$ and $\mathrm{N}$ ). Apparent resistivity " $\rho \mathrm{a}$ " is subsequently deduced. 

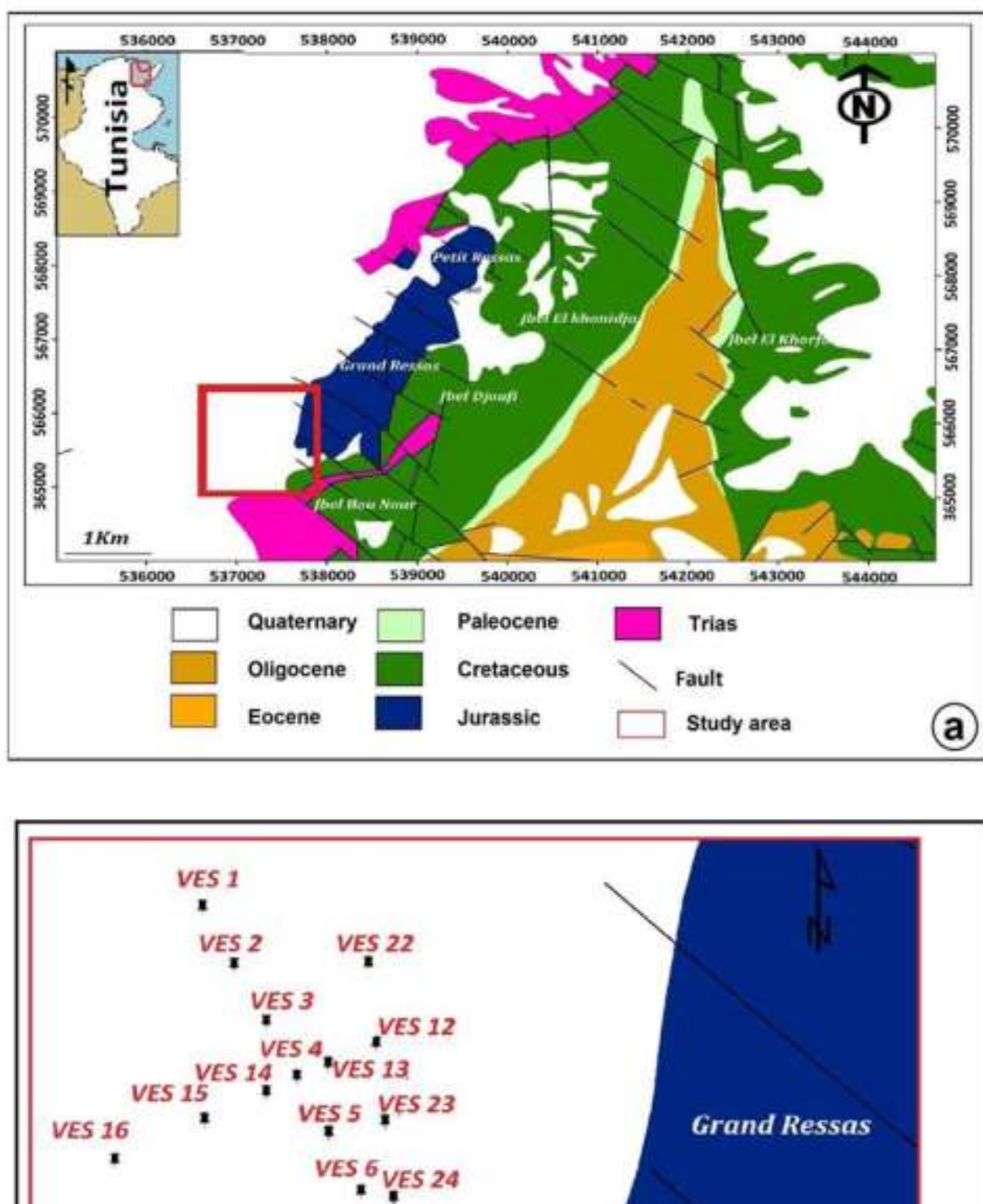

Fights Sailing GE Center - VES 18

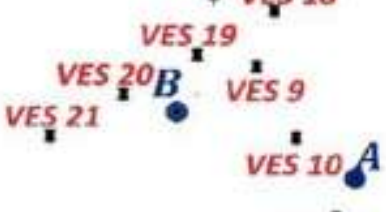

- Borehole VES 11

I Vertical electrical sounding 190

Figure 1. (a) Geological map of Jebel Ressas (Bujalka et al, 1971.); (b) Vertical electrical soundings and boreholes distribution 


\section{Macrothink}
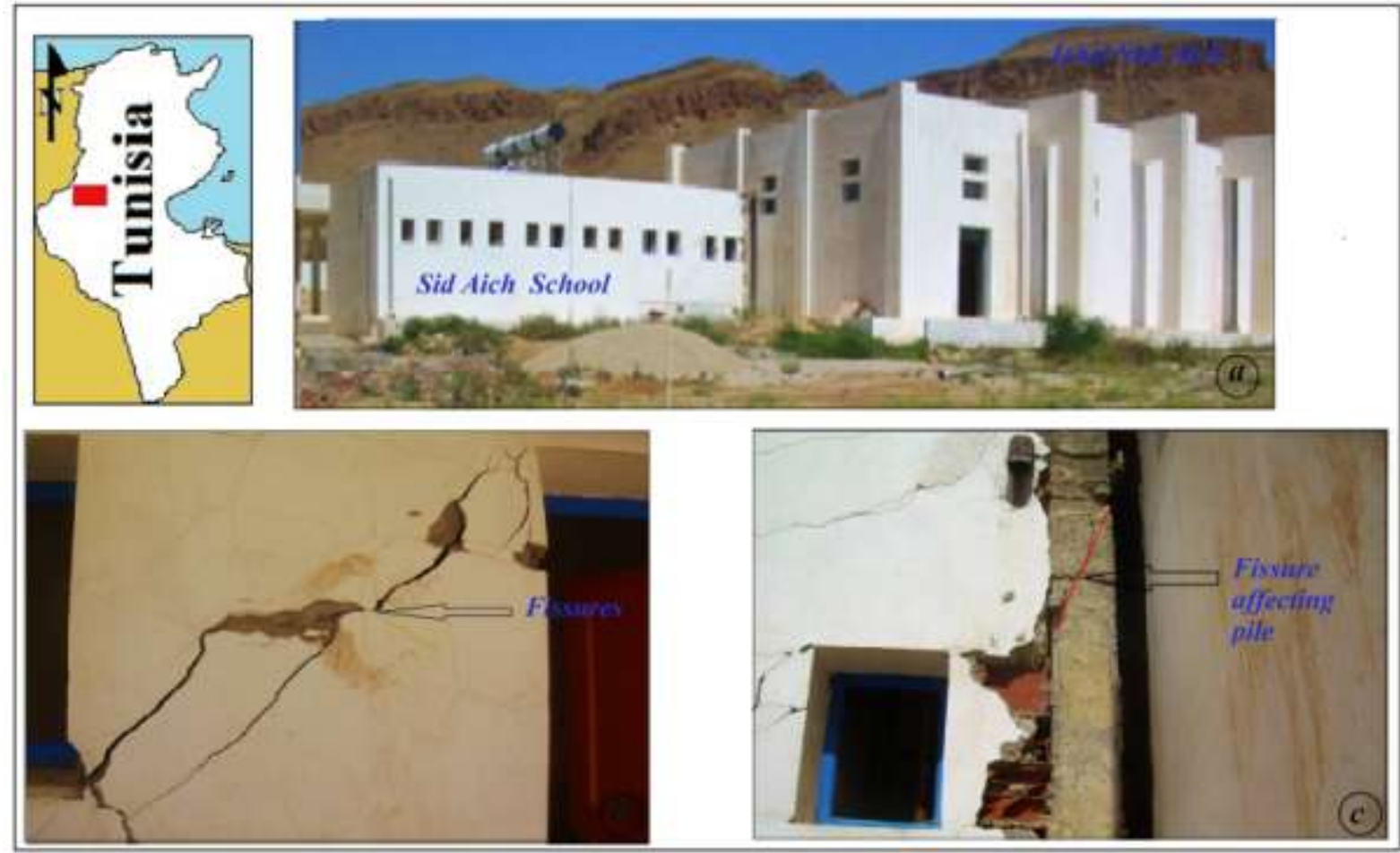

Figure 2. (a) location of Sidi Aich school; (b) Fissures affecting the walls of the school ; (c)

Fissure affecting the piles of the school

Apparent resistivity data, obtained at each vertical electrical sounding for different $A B$ spacings, are arranged and contoured in the form of pseudosections that express a qualitative representation of resistivity distributions.

For quantitative interpretation, the resistivity data were one-dimensionally evaluated. The existing drilled borehole allowed the calibration of the proximal VES.

The determination of initial thicknesses and resistivities are obtained by manual matching the VES field curves to the theoretical master curves and auxiliary point charts. These parameters are subsequently refined using an inverse technique implemented in WINSEV program. The resulting models allow the construction of geoelectrical cross-section.

\subsection{VLF Method}

VLF method utilizes Very Low Frequency radio signals to determine electrical properties of nearsurface soils and shallow bedrock. The used frequency ranges between 15 and $30 \mathrm{KHZ}$ and the measured parameters is the apparent resistivity.

VLF is an effective tool for groundwater investigations (Sundararajan et al. 2007), contaminant mapping (Monteiro Santos et al., 2006) and mineral exploration (Ligas and Palmoba 2006; Ramesh Babu et al. 2007). 


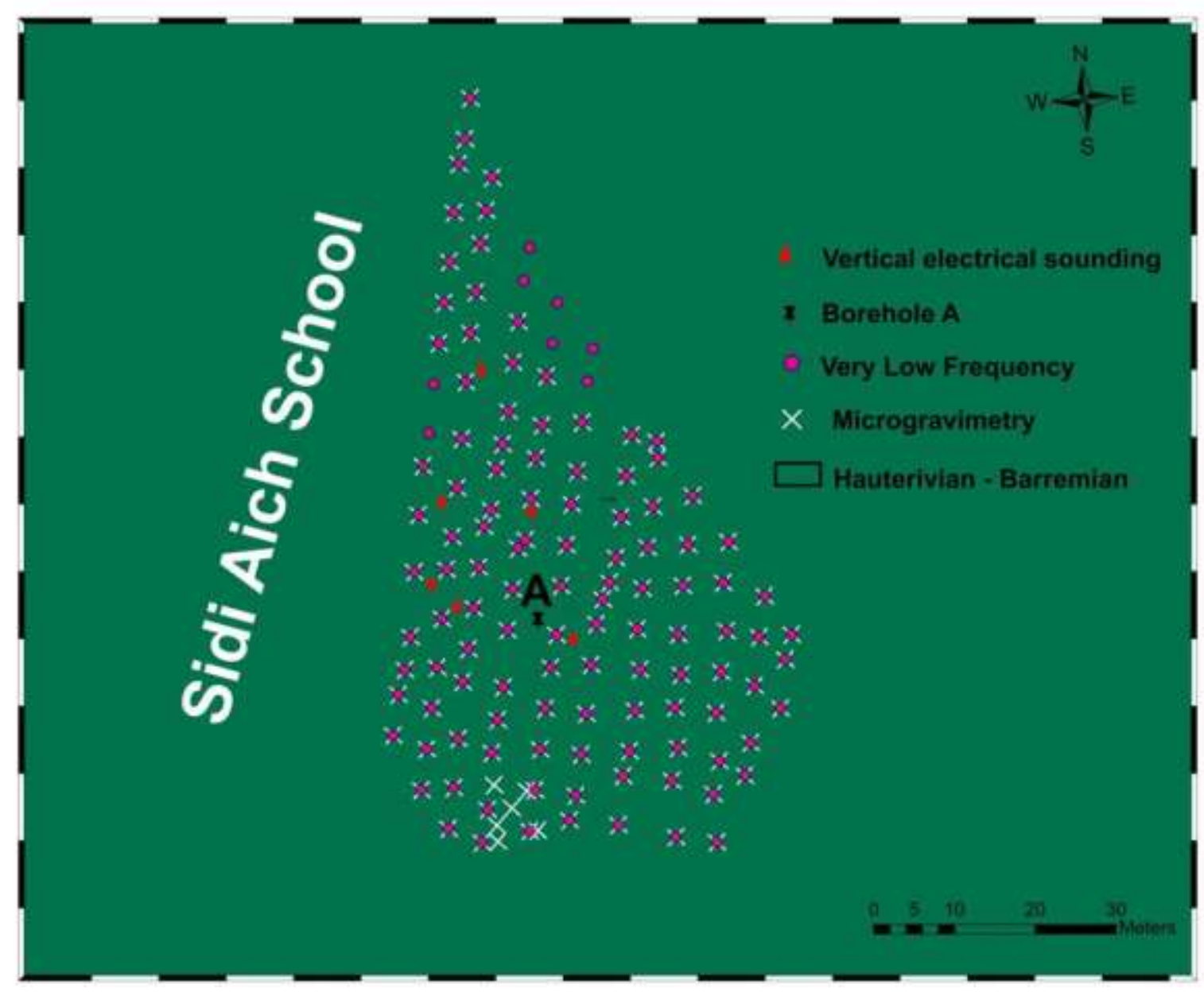

Figure 3. Geophysical measures distribution in Sidi Aich school

\subsection{Microgravemitry}

Microgravimetry method involves measuring with high precisions the earth's gravitational field on the earth's surface to determine the location of subsurface density variations. However, the earth's gravitational field measured at the earth's surface is affected also by topographic changes, the earth's shape and rotation, and earth tides. These factors must be removed before interpreting gravity data for subsurface features. The most commonly used processes data are known as Bouguer gravity anomalies, measured in mGal.

In the civil engineering studies, the microgravimetry method is successfully used for delineating underground cavities (Butler, 1984).

\section{Study Case of Jebel Ressas}

\subsection{Geological Context}

Jebel Ressas belongs to the Tunisian dorsal (Fig.4a), marked by an NE-SW alignment of Jurassic massifs (Castany, 1955; Rakus and Biely, 1970; Bujalka, et al. 1971; Bonnefous, 1972; Rakus, 1973; Perthuisot, 1978; Turki, 1985; Martinez, et al. 1990; Talbi, 1991; Alouani, et al. 1992; Morgan, et al. 1998; Soussi, 2000; Kigui, 2003; Saktni, et al. 2008; Ghorbel et al. 
2010; Mzali, 2010; Jemmali et al. 2011). It is framed by Jebel Bou Karnine of Hammam-Lif in the North and Jebel Zaghouan in the Sud-West (Fig.4a). It is divided in two ridges: the "Petit Ressas" in the North-East and the "Grand Ressas" in the South-West (Fig.1a).

The geological outcrops at Jebel Ressas range from Triassic to Quaternary in age (Fig.1.a). Triassic is represented by clays, gypsums, sandstones, dolomites and limestones. Jurassic series is composed by limestones and dolomites. The Cretaceous is marked by marls and limestones alternations. The Paleocene deposits are constituted by sandy clays and limestones with marly intercalations. The Eocene is represented by limestones and clays. The Oligocene layers are made up of sandy clays, sandstones, sands, clays and gypsums. The Quaternary is characterized by crusts and alluvia.

Additionally to the NE-SW major Zaghouan fault (Fig.4a), extending from Jebel Bou kornine of Hammam Lif to Jebel Bargou, other less important faults with different directions affect Jebel Ressas (Kigui 2003). The E-W faults are distinguished in the western flank of Jebel Ressas. The NW-SE faults compartmentalize Jurassic massifs in independent blocks. The N-S faults are relatively extended with interval spacing of 100 to $200 \mathrm{~m}$.

The map of the epicenters distribution in northern Tunisia (Fig.4b) shows that Jebel Ressas sector is marked by a seismic activity.

\subsection{Geophysical Study}

\subsubsection{Pseudosections}

Three pseudosections (Fig.5) are established from the measured apparent resitivity values. The pseudosection I is oriented NNW-SSE. The pseudosections II and III are directed ENE-WSW.

Pseudosection I (Fig.5a): this pseudosection show high resistivity values (70 to $200 \mathrm{Ohm} . \mathrm{m}$ ) for the distances inferior to $100 \mathrm{~m}$. This may indicate a coarse lithology at the superficial layers. For the distances $\mathrm{AB}$ superior to $100 \mathrm{~m}$, a gradual increase of the apparent resistivity measures is observed from the North to the South. The values range from 10 to $30 \mathrm{Ohm} . \mathrm{m}$ in the northern part (VES1, VES 2 and VES 3). They are between 30 and $50 \mathrm{Ohm} . \mathrm{m}$ in the central part. They reach $90 \mathrm{Ohm} . \mathrm{m}$ in the southern part (VES 9, VES 10 and VES 11)

Pseudosection II (Fig.5b): essentially, it reveals low resistivity values (>40 Ohm .m) which can translate a predominance of clays. The high responses are restricted to the superficial layers with a clear increase from the West to the East where VES12 exposes a value of 120 Ohm.m.

Pseudosection III (Fig.5c): In the eastern extremity of this pseudosection, VES17 and VES 18 expose high resistivity values (65 to 95 Ohm.m) for the greatest distances AB (200 and 300 $\mathrm{m})$. These responses can be attributed to the dolomites Jurassic outcropping in the vicinity of the aforesaid soundings. 

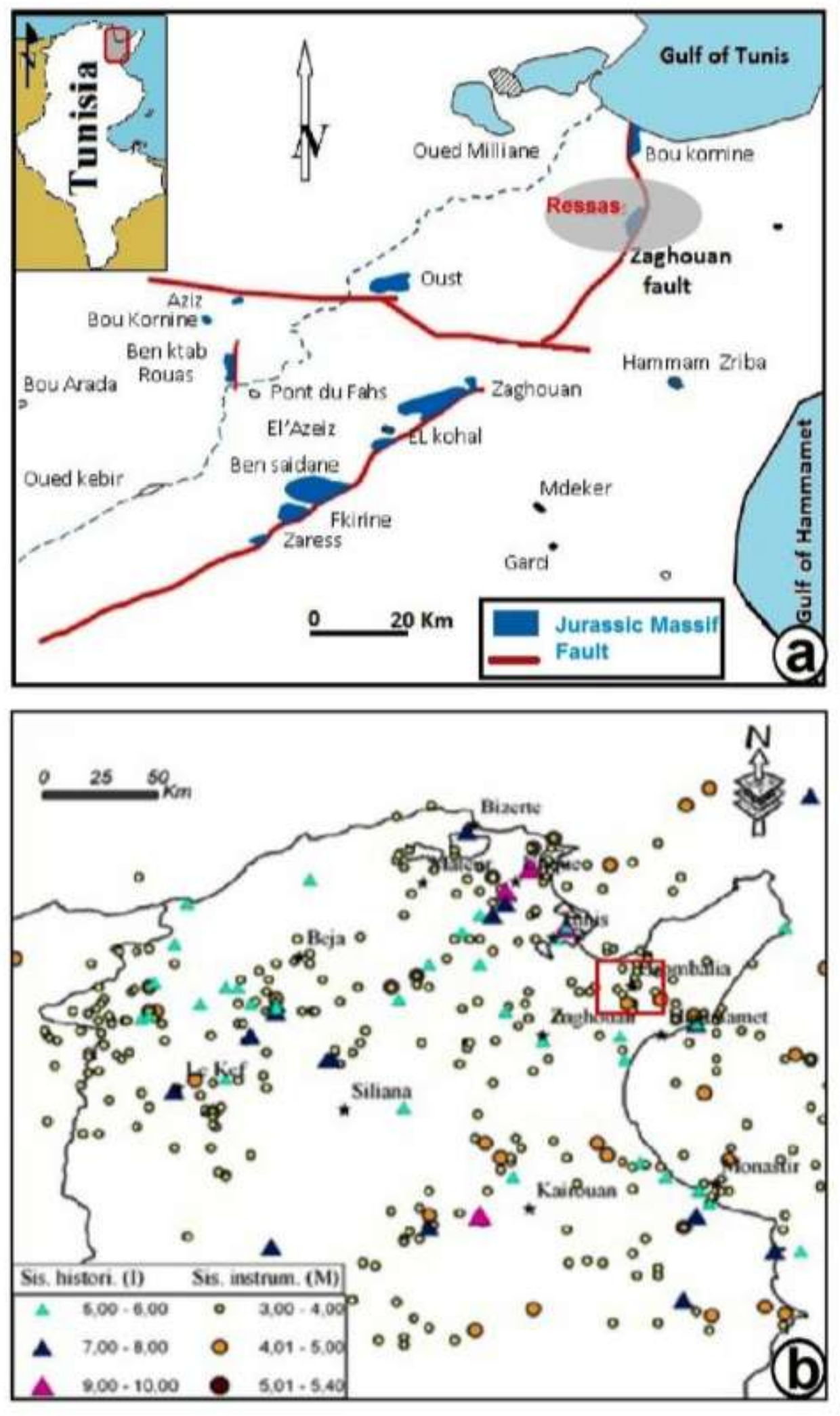

Figure 4. (a) Location of the study area (Castany, 1955). (b): Map of the distribution of epicenters in northern Tunisia from data the National Institute of Meteorology (1975 to 2005) 

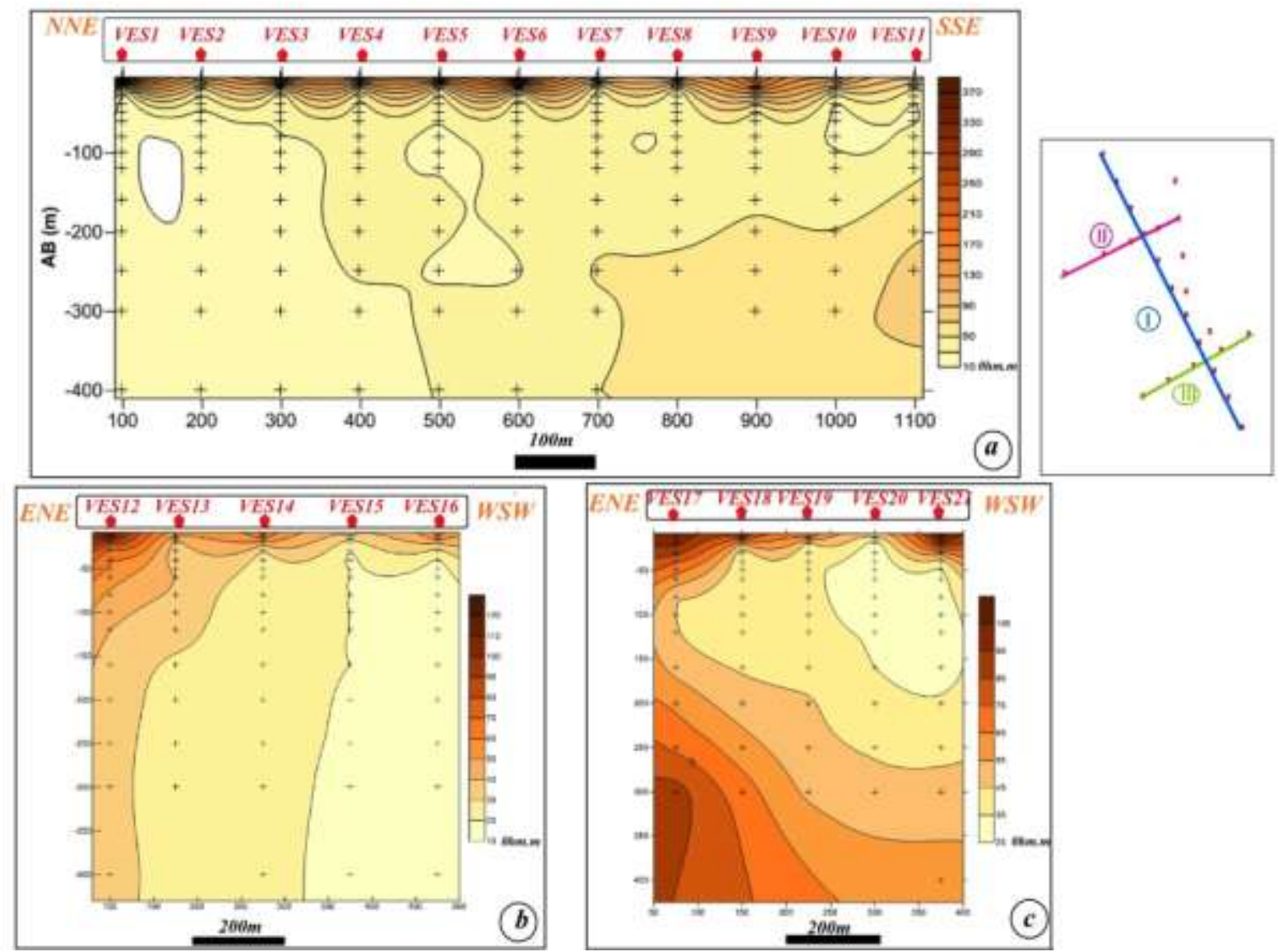

Figure 5. Realized pseudosections

\subsubsection{Vertical Electrical Soundings Calibration}

VES10 calibrated by the lithological column of the borehole A (Fig.6) allows the determination of the specific resistivity of the Quaternary series. Two resistant layers overlaying a conductive layer are identified .The superficial with a resistivity of $256 \mathrm{Ohm} . \mathrm{m}$ characterizes a coarse unity composed of cobbles and dolomite blocks. The more deep, resistant of $134 \mathrm{Ohm} . \mathrm{m}$, corresponds to cobbles with a clayey matrix, The conductive layer (25 Ohm.m) coincides to a clayey entity.

The calibration results, which constitute a guide for the vertical electrical soundings interpretation, are helpful for the construction of the geoelectrical cross-sections. 


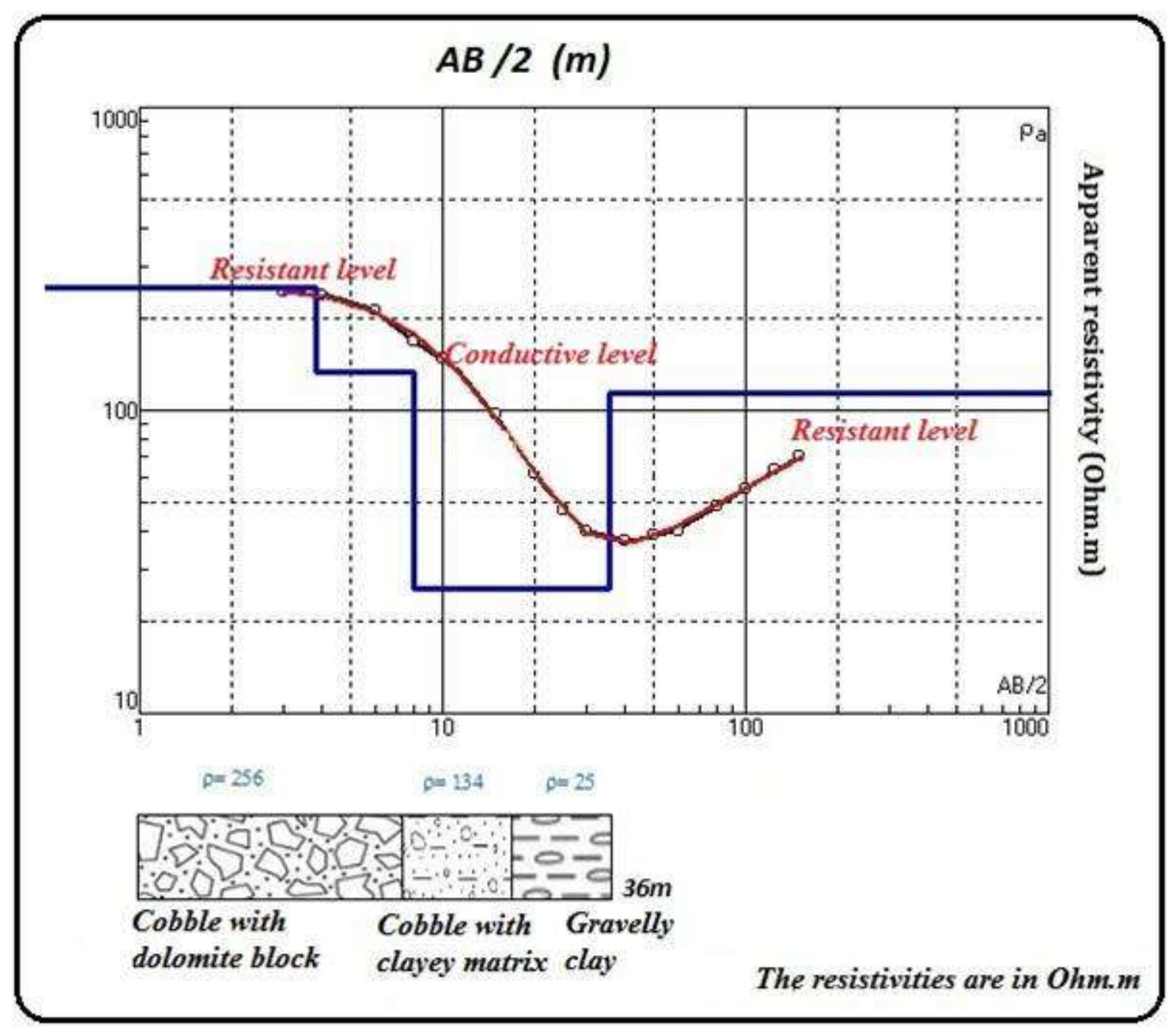

Figure 6. Calibration of SEV 10 by the borehole A

\subsubsection{Geoelctrical Cross Sections}

Adopting the pseudosections directions, three geoelectrical cross sections (Fig.7) are constructed. Through its vertical and horizontal resistivity variations, these sections clearly reflect an irregular subsurface structure.

Geoelectrical cross section I (Fig.7a): the three Quaternary entities recognized by the boreholes $\mathrm{A}$ and $\mathrm{B}$ are identified by the different electrical soundings in this cross section; the cobbles and dolomite blocks reveal an average resistivity of $200 \mathrm{Ohm}$.m. The responses of cobbles with clayey matrix range from 65 to $134 \mathrm{Ohm}$.m. The gravelly clays correspond to low resistivity values (19-26 Ohm.m).

In the southern part of the cross section, the aforementioned layers show a high resistivity zone (150 Ohm.m) that may correspond to the Quaternary deposits substratum, probably Jurassic in age; among the nearby outcrops, only the Jurassic limestones can express an elevated resistivity. This resistive zone depth variation between neighbor soundings VES 9 and VES 10 is attributed to a normal fault generating a remarkable thickening and deepening 
of clayey layers in the depressed northern compartment.

In the cross section center (VES 6, VES 5 and VES 4), the Quaternary deposits are more developed. A third high resistivity layer (50 to $60 \mathrm{Ohm} . \mathrm{m}$ ) that may be correlated with cobbles with clayey matrix is identified. Toward the North, this entity is dropped, the gravelly clays entity is thicker and a very low resistivity layer (5 to 7 Ohm.m) indicating a purely clayey sedimentation is highlighted. This evolution suggests a succession of normal faults affecting the Jurassic substratum and engendering collapses towards the north. Quaternary deposits are thicker and richer in clayey elements in the subsided areas.

Geoelectrical cross section II (Fig.7b): In this cross section western part, VES 16 and VES 15 expose the electric responses of the three Quaternary entities reached by the boreholes A and B: cobbles and dolomite blocks followed by cobbles with clayey matrix and gravelly clays at the base. In the eastern part, a fourth entity is identified. Expressing resistivity values ranging from 35 to $60 \mathrm{Ohm} . \mathrm{m}$, this entity may be constituted of cobbles with clayey matrix.

The sudden resistivity change between the neighbor electrical soundings VES 14 and VES15 imposes a geoelectrical discontinuity that may indicate a fault which collapsed the second entity of cobbles with clayey matrix at the western part of the plain.

Geoelectrical cross section III (Fig.7c): This cross section, realized at the vicinity of a Jurassic outcrop, corroborates the informations extracted from the cross section I; the Jurassic substratum characterized by elevated resistivity values (120 to $225 \mathrm{Ohm} . \mathrm{m}$ ) is affected by normal faults dropping the western compartment of the plain where the Quaternary sediments are thicker.

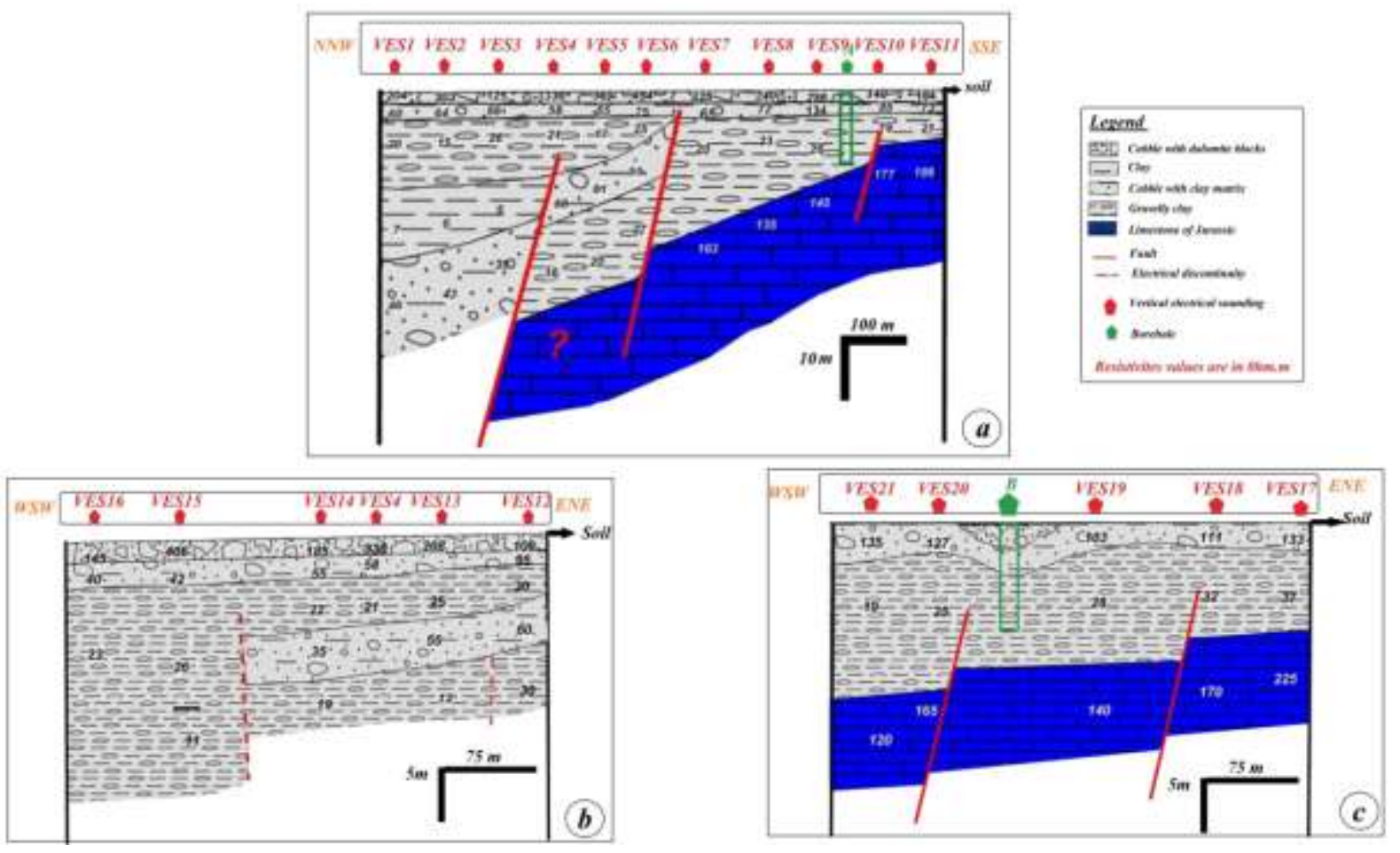

Figure 7. Realized geoelectrical cross sections 


\section{Macrothink}

\subsection{Synthesis}

The interpreated electrical soundings calibrated by the available boreholes determined the sedimentary and tectonic phenomena characterizing the plain at the foot of Jebel Ressas. It shows that the Quaternary deposits filling the plain are generally composed by three lithological entities: cobbles and dolomite blocks at the top, cobbles with clayey matrix and gravelly clays at the base. They overly a Jurassic substratum, affected by normal faults generating collapses toward the North and the West, where the Quaternary clayey layers are thicker. These faults may be active since many earthquakes marked the Jebel Ressas sector.

\section{Study Case of Sidi Aich}

\subsection{Geological Context}

Jebel Sidi Aich belongs to the central Atlas of Tunisia. It is limited by Jebel Ouaddada in the north, Jebel Sounia in the south, Jebel El Hafey in the east and Jebel Atig in the west (Fig8.a).

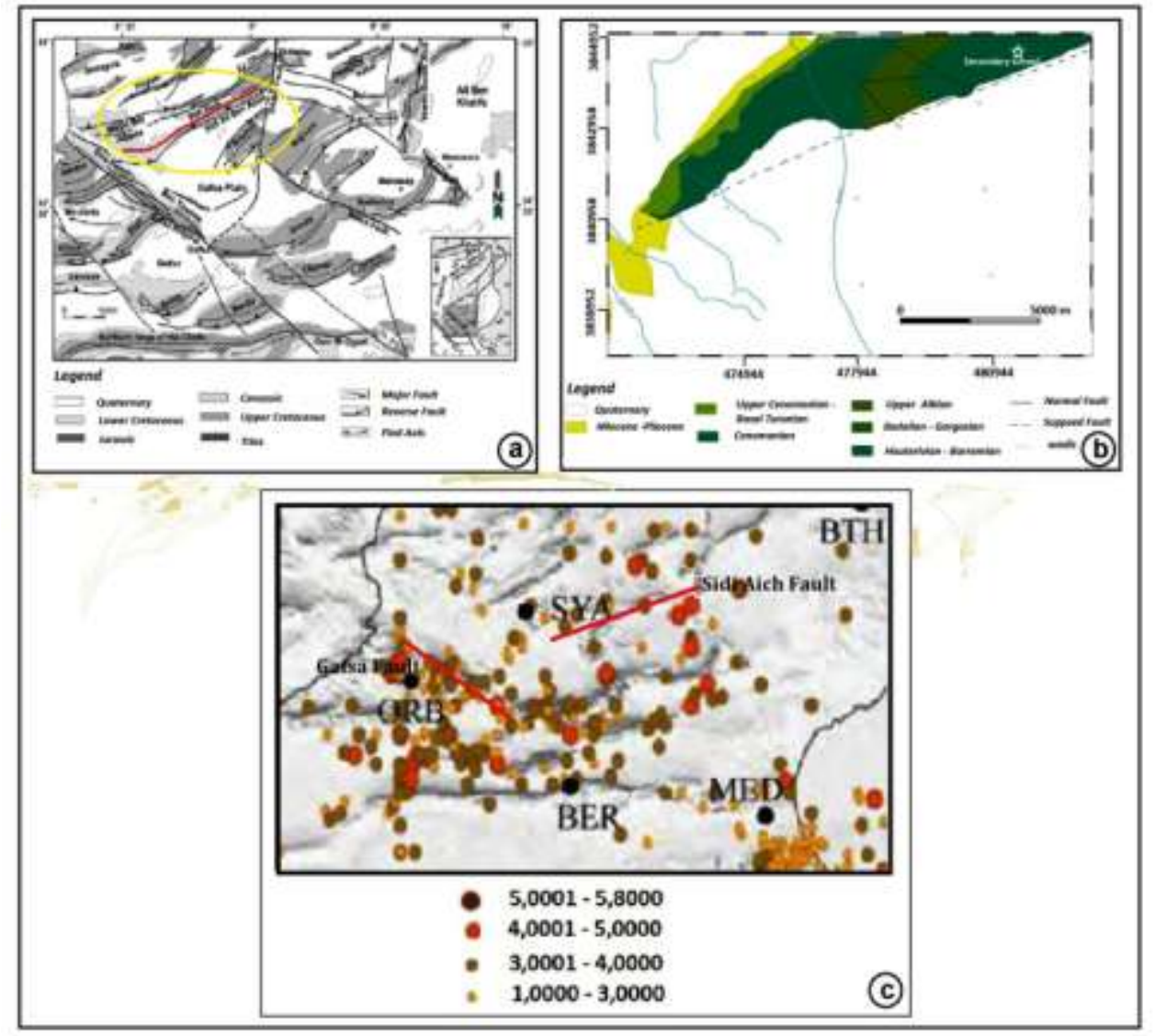

Figure 8. (a) Structural map of the central-southern Atlas (Zouaghi et al., 2009), (b)Situation and geological map of Jebel Sidi Aich (Oueld Ghrib and Sliman,1995), (c) Extract of the seismicity map of Tunisia (data from the National institute of Meteorology from 1975 to 2005)

Stratigraphically, Jebel Sidi Aich is characterized by lower Cretaceous series (Fig8.b) corresponding to Bouhedma, Sidi Aich and Orbata formations (Burollet 1956; M'Rabet 1981; 
Ben Youssef 1999; Gallala et al. 2009)

The Bouhedma formation is very developed. It is mainly clayey with sandy and limestone intercalations. The Sidi Aich formation is composed of sands intercalated with thin clayey layers. The Orbata formation is constituted of clays, dolomites, marls, sandstones and gypsum.

From tectonic point of view, Jebel Sidi is truncated by the Sidi Aich major accident (Zitouni 1997; Boukadi and Bedir 1996; Hlaiem 1999; Bédir et al. 2000; Zouaghi et al. 2009; Gabtni 2006 ;Azaiez et al. 2007; Tanfous 2007). This NE-SW trending fault is responsible of an abnormal contact between the mio-plio-quaternary and the lower Cretaceous series. Seismological data show its continuous activity (Fig.8.c).

Moreover, several faults oriented N90 and N140 are identified at Sidi Aich Jebel (Fig.8.b) .

\subsection{Geophysical Study}

\subsubsection{Vertical Electrical Soundings}

\subsubsection{Pseudosections}

The four realized pseudosections (Fig.9) show a similar resistivity distribution. The high responses are restricted to the short distances $\mathrm{AB}$ (6 to $20 \mathrm{~m}$ ). For the distances 20 to $100 \mathrm{~m}$, the apparent resistivity is between 8 and $30 \mathrm{Ohm} . \mathrm{m}$. This distribution may indicate that the superficial layers are thin, constituted of coarse elements and surmount a thick layer of clays and marls. Additionally, these layers show a lateral resistivity variation. The values increase from VES6 to VES5 and VES 4 in the pseudosection I (Fig.9a), either side of VES 3 in pseudosection II (Fig.9b), from VES6 to VES1 and VES2 in the pseudo section III (Fig.9c) and from VES 3 to VES5 in the pseudosection IV(Fig.9d). This increase suggests a more developed coarse sedimentation.

\subsubsection{Vertical Electrical Soundings Calibration}

The borehole "A" implanted near VES 2 allowed the electrical data calibration (Fig.10). The three meters of tuffs, firstly intersected by this borehole, correspond to a high resistivity of 67 Ohm.m. The thereafter encountred clayey sands is resistant of $33 \mathrm{Ohm} . \mathrm{m}$. It overlies a clayey unit which expresses a response of $5 \mathrm{Ohm} . \mathrm{m}$. The sandy clays at the base shows a resistivity of $18 \mathrm{Ohm} . \mathrm{m}$.

\subsubsection{Geoelectrical Cross Sections}

Four geoelectrical cross sections with the same directions and designations of the pseudosections are constructed (Fig.11). 


\section{Macrothink}

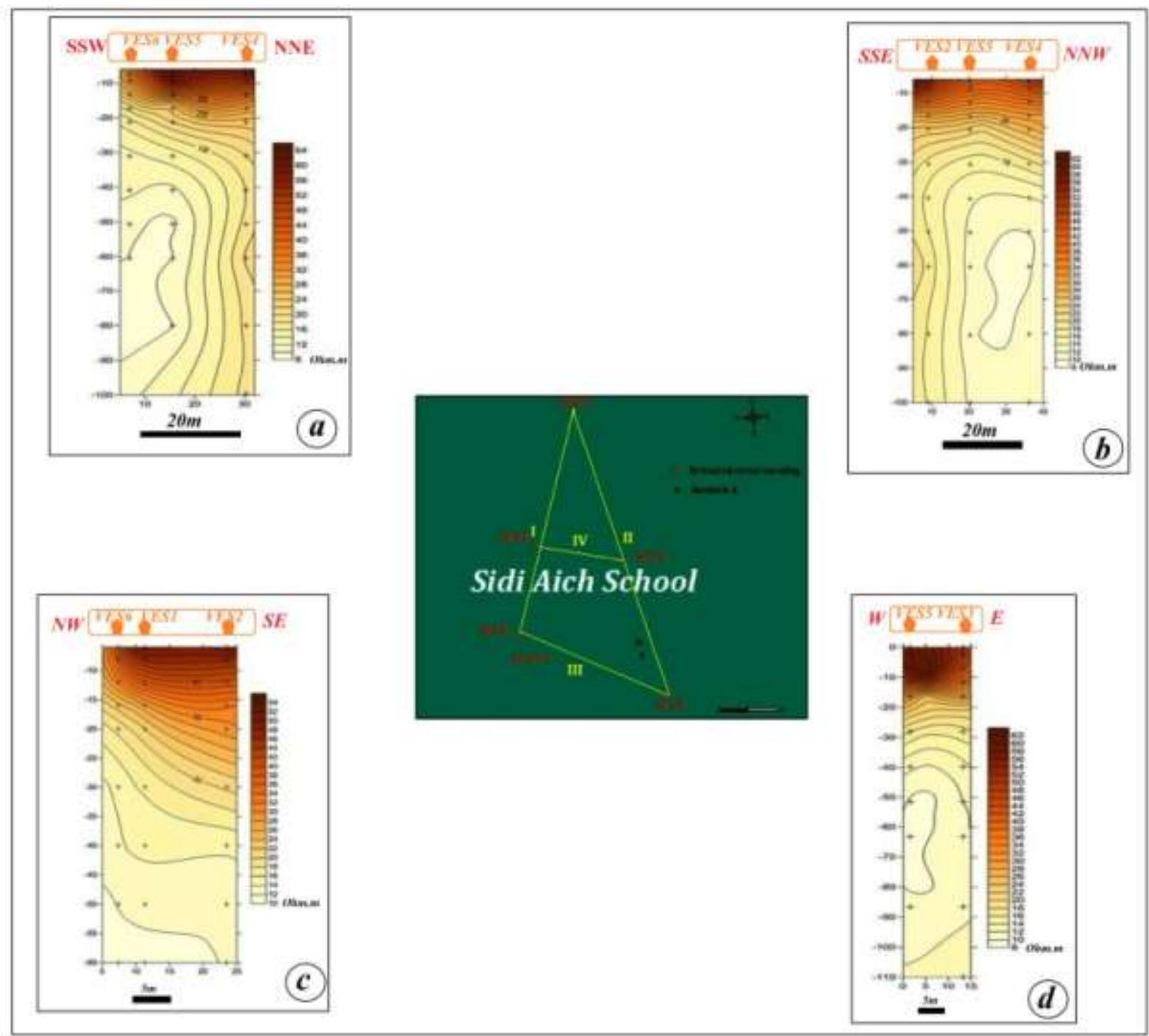

Figure 9. Realized pseudosections

In the cross section I (Fig.11a), VES4 and VES5 expose three layers. The shallow highly resistive (67 to $70 \mathrm{Ohm}$. m) corresponds to tuffs. It surmounts a less resistant (36 to $40 \mathrm{Ohm}$. $\mathrm{m}$ ) composed of clayey sands. The deeper layer shows a low resistivity of 9 to $18 \mathrm{Ohm} . \mathrm{m}$ which characterize a clayey facies. Nearby in VES 6, the tuffs are absent, the clayey sands are firstly encountered and the clays are less deep. This suggests a fault between VES5 and VES6 subsiding the northern compartment.

In the cross section II (Fig.11b) extremities, VES4 and VES2 recognized the same lithological succession: tuffs, clayey sands and clays with similar depth and thickness. In the VES3 at the middle, the clay and clayey sand layers, only prospected, are raised. Two faults placed respectively between VES3 and VES4 and between VES3 and VES2 may be responsible of this uplift. 


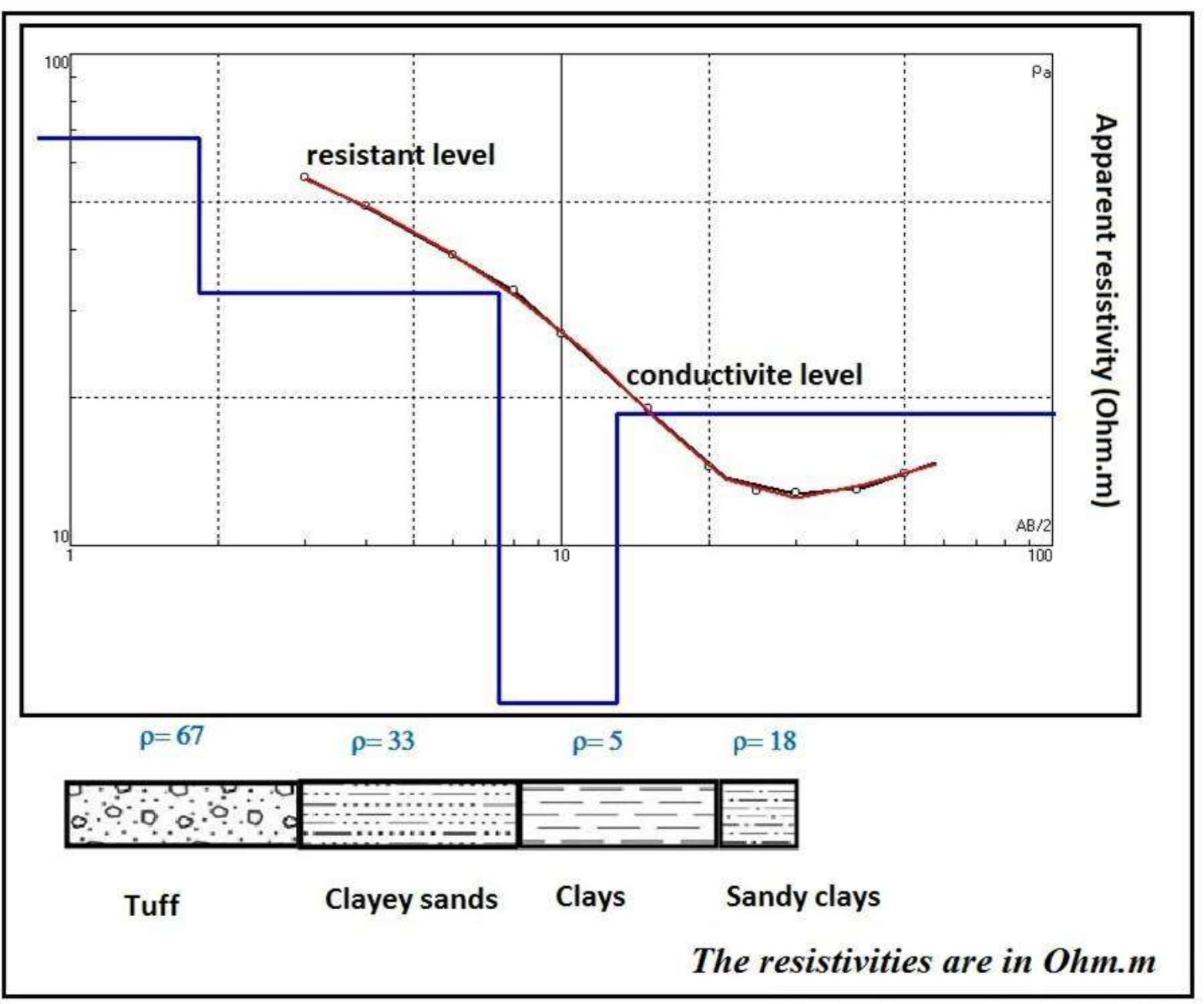

Figure 10. Calibration of SEV2 by the borehole A

The cross section III (Fig.11c) integrates VES 6, VES 1, VES 2 and the borehole A. Going from VES 1 to VES2, the clay layer is depressed and the clayey sand layer shows a remarkable thickening. This abrupt change may be explained by a tectonic accident between the electrical soundings.

Equally, the cross section IV (Fig.11d) shows significant variation of the clay depth between VES3 and VES5. A fault is therefore deduced. 

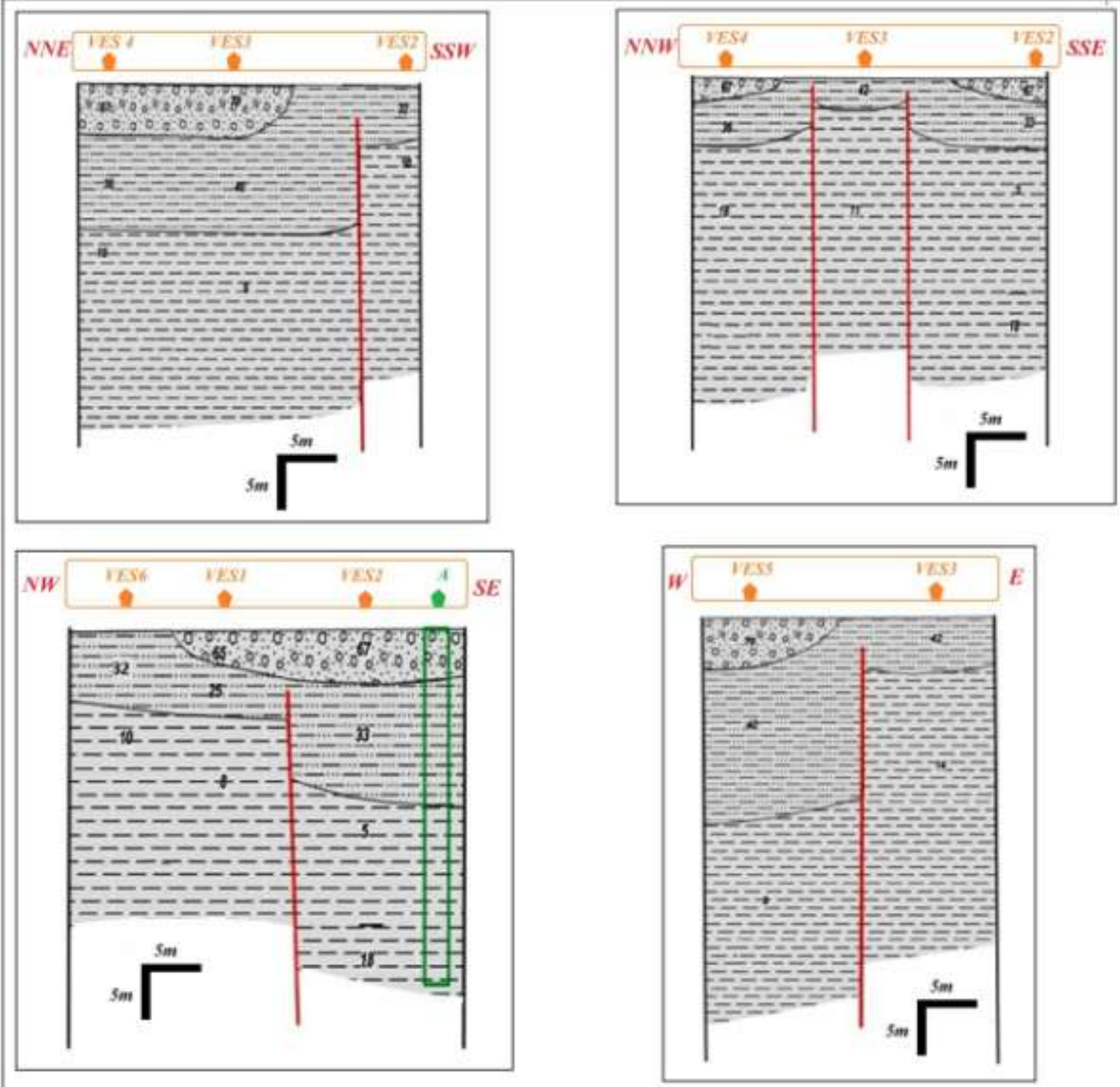

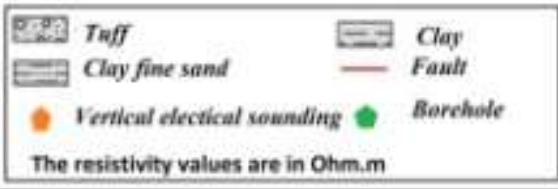

Figure 11. Realized geoelectrical cross sections

The correlation between the four geoelectrical reveals that the school underground is affected by two NE-SW faults (Fig.12) limiting a raised zone. These faults may represent sections of the major fault of Sidi Aich. 


\section{Macrothink}

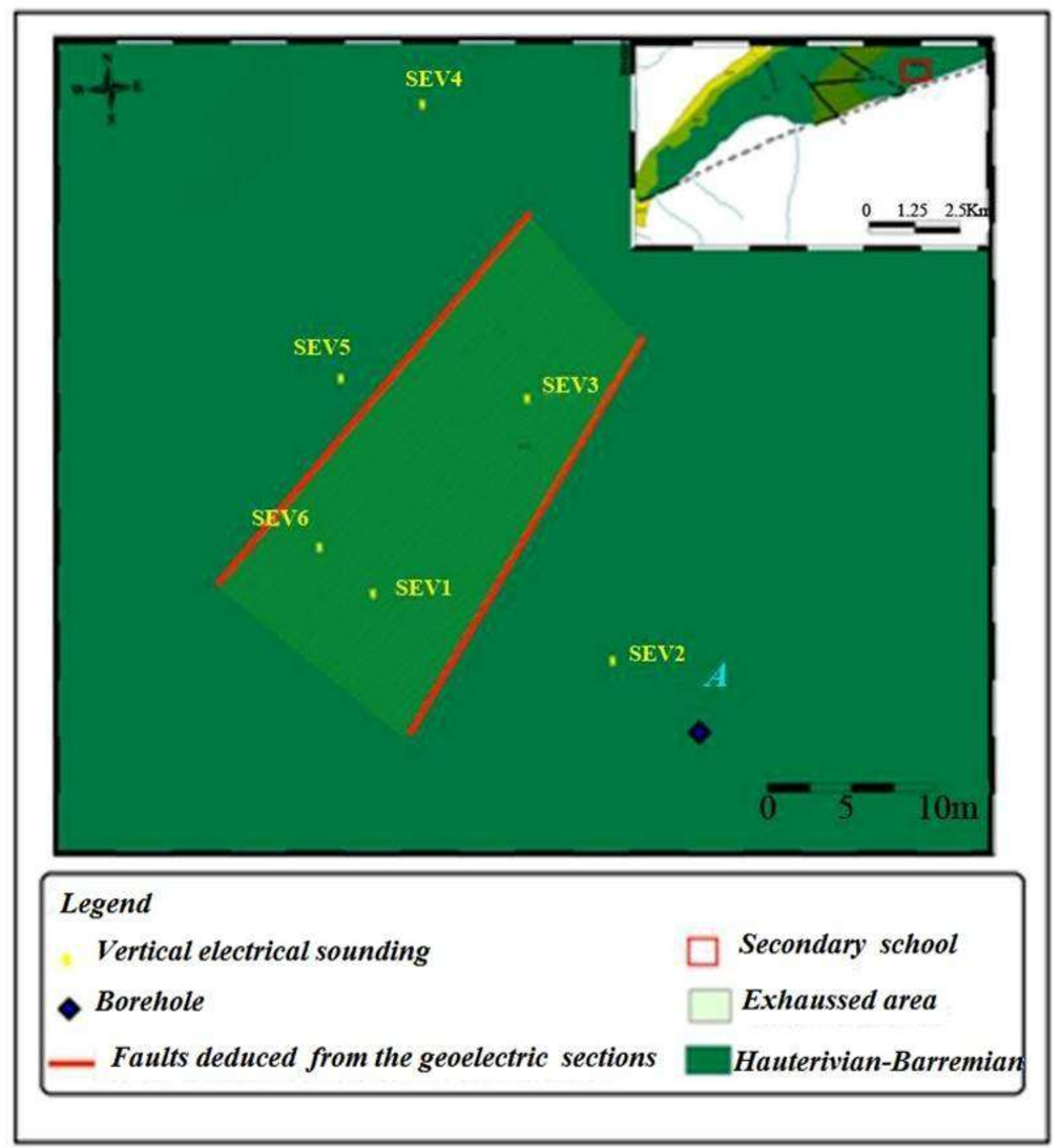

Figure 12. Tectonic deformations deduced from geoelctrical sections

\subsubsection{VLF Profiles}

The apparent resistivity map established for the frequency $18300 \mathrm{~Hz}$ (Fig. 13a) shows clearly two compartments. The eastern compartment is homogenous with low resistivity indicating clayey lithology. The western compartment reveals important resistivity variation; the profiles 2 and 4 express high responses (30 to $60 \mathrm{Ohm} . \mathrm{m}$ ) which can be the electrical equivalents of tuffs and clayey sands. The profiles 1,3 and 5 show low resistivity ( 8 to $30 \mathrm{Ohm} . \mathrm{m}$ ) correlated with clays. Manifested by tight curves, the abrupt resistivity change between profiles may be explained by brittle deformations. Four faults directed NE-SW to NNE-SSW are identified (Fig.13). 


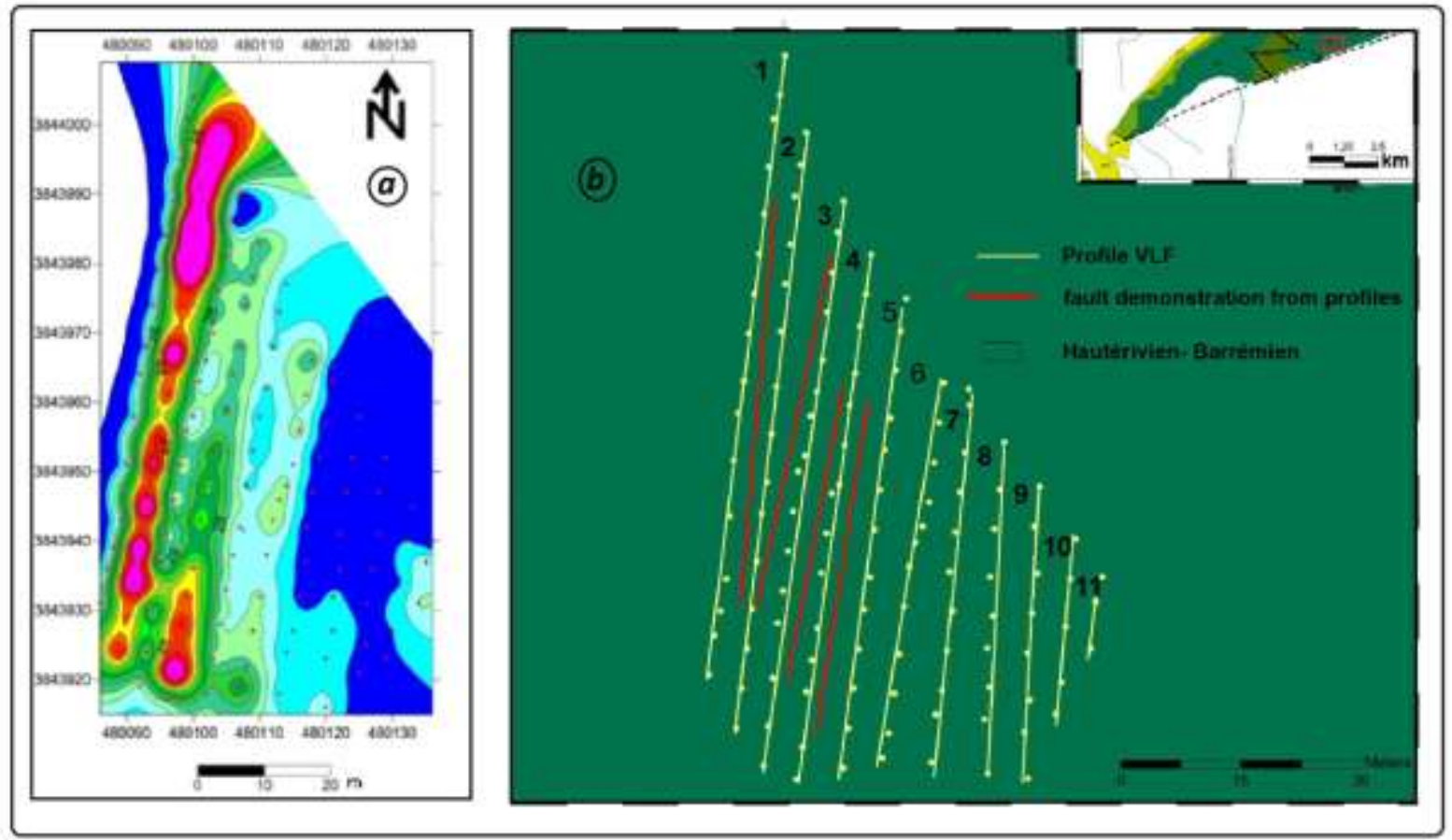

Figure 13. a: Apparent resistivity maps: $F=18300 H Z$. b: Faults deduced from VLF profiles

\subsubsection{Microgravimetry}

The map deduced from microgravimetric measures (Fig.14) shows amplitudes ranging from 0.3 to 0.35 mgals. These low values reflect the absence of a density contrast between the prospected lithological facies. In fact, the borehole " $\mathrm{A}$ " implanted in the study area shows mainly sands, clayey sands, clays and sandy clays. These facies are characterized by similar densities (density of sand is 1.9 and the clay is 2).

\subsection{Synthesis}

Vertical electrical soundings and VLF methods were successfully applied to identify the tectonic deformations that damage the Sidi Aich school; they highlighted NE-SW to NNE-SSW faults. As portions of the major accident of Sidi Aich, these faults are characterized by seismic activity. Thus, adopting a paraseismic construction, would avoid the produced damages.

The microgravimetry data don't furnish any indication about the underground geometry of the Sidi Aich school since the litholgical formations are characterized by similar densities. 


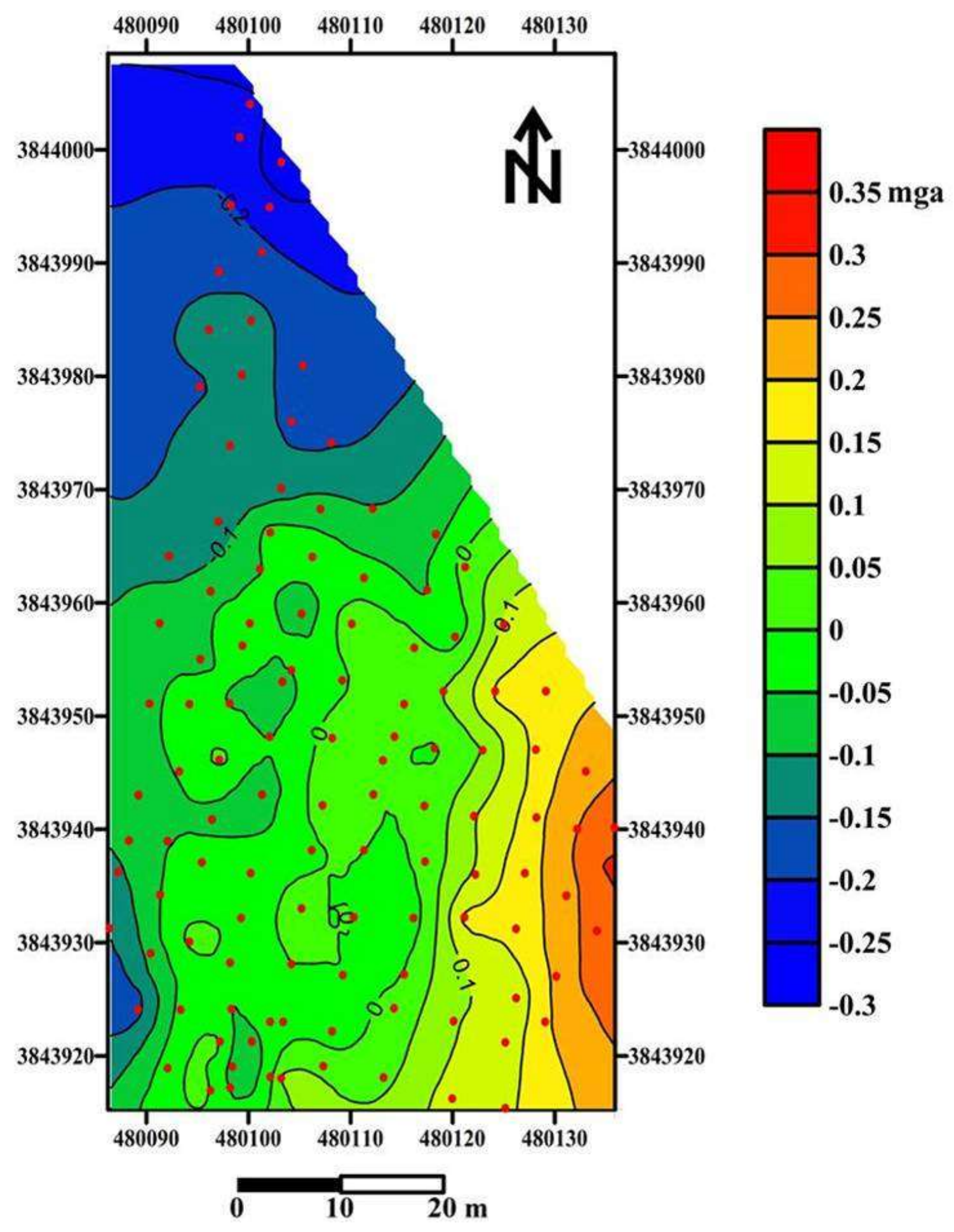

Figure 14. Microgravity map

\section{Conclusion}

Through the presented study cases, geophysics appears as a necessary approach, able to avoid and solve many problems. In fact, the construction of Sidi Aich without the soil reconnaissance caused serious damages. Moreover, the choice of the adequate geophysical methods for every study case is primordial to guarantee a successful application. A detailed 
analysis of the available geological data (geological map, borehole...) can enormously contribute to this choice. Additionally, the compilation of different geophysical methods is useful to check the obtained results.

\section{References}

Alouani, R., Raïs, J., Sahiro, G., \& Tlig S. (1992). Les structures en décrochement au Jurassique de la Tunisie de Nord: Témoin d.une marge transformante entre Afrique et Europe. ComptesRendus Académie Sciences Paris, t. 315, série II, 717-724.

Azaiez, H., Bedir, M., Tanfous, D., \& Soussi M. (2007). Seismic sequence stratigraphy and platform to basin reservoir structuring of Lower Cretaceous deposits in the Sidi Aich-Majoura region (Central Tunisia). Journal of African Earth Sciences, 48, 1-18. http://dx.doi.org/10.1016/j.jafrearsci.2007.02.009

Bédir, M., Zitouni, L., Boukadi, N., Saadi, J., Alouani, R., BenTimzal, F., Tlig, S., \& Ben, Y. M. (1999). Stratigraphie génétique du Crétacé de Tunisie, micropaléantologie, stratigraphie séquentielle et géodynamique des bassins de la marge sud et péritéthysienne. Thèse d'Etat.Univ. Tunis II, p402.

Beres, M., Luetscher, M., \& Olivier, R. (2001). Integration of ground-penetrating radar and microgravimetric methods to map shallow caves. Journal of Applied Geophysics, 46, 249-262. http://dx.doi.org/10.1016/S0926-9851(01)00042-8

Biely, A., \& Rakus, M. (1970). stratigraphie du lias dans la Dorsale tunisienne. Notes Sev.Géol.tunisie, 32, 45-63.

Bobier, C. (2000). Rifting, halocinése et structuration des bassins péri-téthysiens jurassiques et crétacés inférieurs de subsurface du domaine atlasique central de la Tunisie (région de Gafsa-Sidi Ali Ben Aoun). AfricaGeoscienceReview, 7, 289-306.

Bonnefous, J. (1972). Contribution à l'étude stratigraphique et micro paléontologique du Jurassique de Tunisie (Tunisie septentrionale et centrale, Sahel, zone des chotts). Thèse d'Etat. Univ. Paris VI. p397.

Boukadi, N., \& Bédir, M. (1996). L'halocinèse en Tunisie, Contexte tectonique et chronologie des évènements. C.R. Acad. Sci., 322, 587-594.

Buljalk, P., Johan, Z., Krivy, M., Rkus, M.. \& Vacek J. (1971). Notice explicative et Carte géologique de Grombalia 1/50 000 (feuille $\mathrm{N}^{\circ}$ 29). Publication du Service Géologique de Tunisie.

Burollet, P. F. (1956). Contribution à l'étude stratigraphique de la Tunisie centrale. Annales des Mines et de la Géologie, 18, 352.

Butler, D. K. (1984). Microgravimetric and gravity gradient techniques for detection of subsurface cavities. Geophysics, 49, 1084 -1096. http://dx.doi.org/10.1190/1.1441723

Castany, G. (1955). Les extrusions jurassiques en Tunisie. Annales des Mines et de la géologie, 14, 71. 
El Khammari, K., Najine, A., Jaffal, M., Aïfa, T., Himi, M., Vásquez, D., Casas, A, \& Andrieux, P. (2007). Imagerie combinée géoélectrique-radar géologique des cavités souterraines de la ville de ZaouitEch Cheikh (Maroc). C.R. Acad. Sci., 339, 460-467.

Frappa, M., \& Muraour, P. (1980). Aseismic method for the detection of subsurface cavities. Geoexploration, 18, 177-185. http://dx.doi.org/10.1016/0016-7142(80)90029-0

Gabtni, H. (2006). Caractérisation profonde et modélisation géophysique des zones de transition entre les différents blocs structuraux de la Tunisie centro-méridionale. Thèse de Doctorat, Univ. Tunis E1 Manar, p243.

Gallala, W., Gaied, M. E., \& Montacer, M. (2009). Detrital mode mineralogy and geochemistry of the SidiAïch Formation (Early Cretaceous) in central and southwestern Tunisia: Implicationsfor provenance, tectonic setting and paleoenvironment. Journal of African Earth Sciences, 53, 159-170. http://dx.doi.org/10.1016/j.jafrearsci.2009.01.002

Ghorbel, M., Munoz, M., Courjault-Rade, P., Destrigneville., C, de Parseval, P., Souissi, R., Souissi, F., Ben Mammou, A., \& Saadi A. (2010).Health risk assessment for human exposure by direct ingestion of $\mathrm{Pb}, \mathrm{Cd}, \mathrm{Zn}$ bearing dust in the former miners' village of Jebel Ressas (NE Tunisia). Eur. J. Mineral., $22, \quad 639-649$. http://dx.doi.org/10.1127/0935-1221/2010/0022-2037

Grandjean, G., Pennetier, C., Bitri, A., Meric, O., \& Malet J. P. (2006). Caractérisation de la structure interne et de l'état hydrique de glissements argilo-marneux par tomographie géophysique : l'exemple du glissement-coulée de Super-Sauze (Alpes du Sud, France). C.R. Acad. Sci., 338, 587-595.

Hlaiem, A. (1999). Halokinesis and structural evolution of the major features in eastern and $\begin{array}{lllll}\text { Southern Tunisian } & \text { Atlas. } & \text { Tectonophysics, } & 306, & \text { 79-95. }\end{array}$ http://dx.doi.org/10.1016/S0040-1951(99)00045-1

Jemmali, N., Souissi, F., Vennemann, T. W., \& Carranza, E. J. (2011). Genesis of the Jurassic Carbonate- Carbonate - Hosted $\mathrm{Pb}-\mathrm{Zn}$ deposits of Jebel Ressas (North - Eastern Tunisia): Evidence from minerology, petrography and trace metal contents and isotope $(0, \mathrm{C}, \mathrm{S}, \mathrm{Pb})$ geochemistry. Resource Geology, 61(4), 367-383. http://dx.doi.org/10.1111/j.1751-3928.2011.00173.x

Keller, G. V., \& Frischknecht, F. C. (1982). Electrical Methods in Geophysical Prospecting. Oxford: Pergamon Press.

Khalldaoui, F., Djeddi, M., \& Abtout A. (2009). Reconnaissance d'un environnement karstique et Fissure par les méthodes géophysiques (cas de Ain Benian Sud -Est d'alger).Quatrième Congrès Maghrébien de géophysique appliquée, 25-28 mars 2009.

Kigui, D. (2003). Analyse de la fracturation du Jurassique du JebelRessas-recherche du schéma de tir optimum. Thèse 3eme cycle. Univ.Tunis, p196.

Ligas, P., \& Palmoba, M. (2006). An integrated application of geological-geophysical methodologies as a cost-efficient tool in improving estimation of clay deposit potential: Case 
study from South-Central sardine (Italy). Ore Geology Reviews, 29, 162-175. http://dx.doi.org/10.1016/j.oregeorev.2005.11.006

M'Rabet, A. (1981). Stratigraphie, sédimentation et diagenèse des séries du Crétacé inférieur de Tunisie Centrale. D. Sc. Thesis. Université de Paris Sud Orsay. France, p540.

Martinez, C., Turki M. M., \& Truillet, R. (1990). La signification des plis dorientationmeridienne dans l'Atlas tunisien centro-septentrional. Bull. Soc. Geol. France, Paris, 6(5), 843-852.

Monteiro Santos, F. A., Mateus, A., Figueiras, J., \& Gonçalves, M. A. (2006). Mapping groundwater contamination around a landfill facility using the VLF-EM method-a case study. Journal of Applied Geophysics, 60, 115-125. http://dx.doi.org/10.1016/j.jappgeo.2006.01.002

Morgan, M., Grocott, J., \& Moody, R. (1998). The structural evolution of the Zaghouan-Ressas Structural Belt, northern Tunisia. Geol. Soc. Lond. Spec. Publ., 132, 405-422. http://dx.doi.org/10.1144/GSL.SP.1998.132.01.23

Mzali, H. (2010). Etude des déformations et évolution des paléocontraintes dans la région de Bouficha-Grombalia. Thèse de doctorat, Université El Manar II, FST, p120.

Perthuisot, V. (1978). Dynamique et pétrogenèse des extrusions triasiques en Tunisie septentrionale. Thèse es Sciences. Travaux du Laboratoire de Géologie, 12. Presse de L'école normale supérieure de Paris, p312.

Rakus, M. (1973). le jurassique du JebelRessas (Tunisie septentrionale), in Livre Jubilaire Marcel Soligniac, Annales de Mines et géologie. $\mathrm{n}^{\circ} 26$ Tunis, 137-147.

Ramesh Babu, V., Subhash, R., \& Sundararajan N. (2007). Modeling and inversion of magnetic and VLF-EM data with an application to basement fractures: A case study from Raigarh, India. Geophysics, 72, 133-140. http://dx.doi.org/10.1190/1.2759921

Saktani, N., Faure, P., Alouani, R., \& Zargouni F. (2008). Le passage Lias-Dogger de la dorsale de Tunisie septentrionale. Nouveaux apports biostratigraphie.âge Toarcien suérieur de la distension téthysienne. $\quad$ C.R.Palevo, $\quad 7, \quad 185-194$. http://dx.doi.org/10.1016/j.crpv.2008.03.001

Schmutz, M., Guérin, R., Maquaire, O., Descloîtres, M., Schott, J. J., \& Albouy, Y. (1999). Apport de l'association des méthodes TDEM (Time-Domain Electromagnetism) et électrique pour la connaissance de la structure du glissement-coulée de Super Sauze (bassin de Barcelonnette, Alpes-de-Haute-Provence, France). C.R. Acad. Sci., 328, 797-800.

Soussi, M. (2000). Le Jurassique de la Tunisie atlasique : Stratigraphie, Dynamique sédimentaire, Paléogéographie et Intérêt pétrolier. Thèsed'Etat.Univ. Tunis. p616.

Sundararajan, N., Nandakumar, G., Chary, M. N., Ramam, K., \& Srinivas, Y. (2007). VES and VLF - an application to groundwater exploration, Khammam, India. Geophysics 6-26.

Talbi, F. (1991). Dynamique des faciès jurassiques, structuration syndépôt et minéralisation (pb- Zn) du Jebel Ressas, DEA ;Univ.Tunis, p87. 
Tanfous, D. (2007). Sismostratigraphie et sismotectonique du Jurassique dans l'Atlas centro-méridional deTunisie, Thèse de Doctorat, Univ.Tunis, p249.

Turki, M. M. (1985). Polycinématique et contrôle sédimentaire associé sur la cicatrice Zaghouan-Nebhana. Thèse d'Etat.Univ Tunis. p252.

Zitouni, L. (1997). Evolution géodynamique des bassins mésozoïques de subsurface des régions de Sidi Aïch-Majoura (Tunisie Centrale): Sismostratigraphie, sismo-structurale et implications pétrolières. Thèse de Doctorat. Université de Tunis II, p335.

Zouaghi, T., Bédir, M., Abdallah, H., \& Inoubli, M. H. (2009). Seismic sequence stratigraphy, basin structuring, and hydrocarbon implications of Cretaceous deposits (Albian-Maastrichtian) in central Tunisia. Cretaceous Research, 30, 1-21. http://dx.doi.org/10.1016/j.cretres.2008.02.005 